\title{
REKONSTRUKSI NILAI-NILAI PENDIDIKAN KARAKTER PADA PENINGGALAN PURBAKALA DI DESA PAKRAMAN SELULUNG, KINTAMANI, BANGLI SEBAGAI SUMBER BELAJAR IPS DI SMP
}

\author{
I Wayan Pardi', Luh Putu Sendratari², I Ketut Margi ${ }^{3}$ \\ Program Studi Pendidikan IPS, Universitas Pendidikan Ganesha Singaraja, Indonesia \\ e-mail: iwayanpardi@gmail.com¹, Ipsendra@yahoo.co.id ${ }^{2}$, ketut.margi@yahoo.co.id ${ }^{3}$
}

\begin{abstract}
Abstrak
Penelitian ini bertujuan untuk: (1) Mengidentifikasi jenis peninggalan purbakala yang ada di Desa Pakraman Selulung, Kintamani, Bangli, (2) Mengidentifikasi nilai-nilai pendidikan karakter yang terkandung di dalam peninggalan purbakala di Desa Pakraman Selulung, (3) Menganalisis nilai-nilai pendidikan karakter pada peninggalan purbakala yang bisa dimanfaatkan sebagai sumber belajar IPS di SMP, dan (4) Menganalisis cara pengintegrasian nilai-nilai pendidikan karakter yang terdapat dalam peninggalan purbakala dalam perangkat pembelajaran IPS di SMP. Metode yang digunakan dalam penelitian ini adalah metode kualitatif dengan langkah-langkah, yakni penentuan lokasi penelitian, metode penentuan informan, metode pengumpulan data, istrumen penelitian, metode pengujian keabsahan data, dan metode analisis data. Hasil temuan: (1) Jenis peninggalan purbakala di Desa Pakraman Selulung adalah Punden Berundak, Arca Megalitik, Menhir, Hiasan Tanduk Kerbau, Batu Alam, Lempengan Batu, kerang, Arca bercorak Tiongkok, Arca Hindu, Arca Perunggu, Lingga Yoni, Gamelan Kuno, dan batu berbentuk roda. (2) Nilai-nilai pendidikan karakter dalam peninggalan purbakala adalah karakter religius, jujur, toleransi, disiplin, kerja keras, kreatif dan inovatif, mandiri, demokratis, rasa ingin tahu, cinta tanah air, gotong royong, hormat, peduli lingkungan, tanggung jawab, berani mengambil resiko, tangguh, terbuka, ramah dan luwes, moderat, dan seni. (3) Nilai-nilai pendidikan karakter pada peninggalan purbakala dapat diaplikasikan sebagai sumber belajar IPS di SMP kelas VII pada standar kompetensi memahami lingkungan kehidupan manusia dan kompetensi dasar mendeskripsikan kehidupan pada masa pra aksara di Indonesia. (4) Nilai-nilai pendidikan karakter dalam peninggalan purbakala diintegrasikan ke dalam silabus dan rencana pelaksanaan pembelajaran IPS ke dalam aspek tujuan, indikator, materi, strategi dan metode, langkah-langkah, dan penilaian pembelajaran.
\end{abstract}

Kata Kunci: Peninggalan purbakala, Karakter, Perangkat Pembelajaran

This study aims to (1) Identify type of ancient relics in the Pakraman Selulung village, Kintamani, Bangli, (2) Identifying the educational values embodied in the character of ancient relics in the Pakraman Selulung village, (3) Analyzing the values of character education in ancient relics that can be used as a source of social studies in junior high school, and (4) Analyzing how the integration of character education values contained in the ancient relics in the learning social studies in junior high school. The method used in this study is a qualitative method steps, namely the determination of the location of the research, the method of determining the informant, data collection methods, instrument of research, methods of testing the validity of data, and data analysis methods. The findings: (1) Type of ancient relics in the Pakraman Selulung village is Punden Berundak, statue of Megalitik, Menhir, Buffalo Horn Ornament, Natural Stone, Stone Slabs, shells, statue patterned Chinese, Hindu statue, bronze statue, Yoni Phallus, Ancient Gamelan, and a wheel shaped stone. (2) The values of character education in archaeological heritage is religious character, honesty, tolerance, discipline, hard work, creative and innovative, independent, democratic, curiosity, love of the homeland, mutual cooperation, respect, care for the environment, responsibility, dare to take risks, resilient, open, friendly and flexible, moderate, and the arts. (3) The values of character education at the reconstructed ancient relics can be applied as a source of social studies in junior high school class VII on environmental standards of competence to understand human life and basic competence describing life in pre characters in Indonesia. (4) The values of character education in ancient relics are integrated into the syllabus and lesson plan IPS into aspects of the objectives, indicators, materials, strategies and methods, measures, and assessment of learning.

Keywords: Ancient Relics, Character, Learning Tool 


\section{PENDAHULUAN}

Bangsa Indonesia dewasa ini sedang dihadapkan pada problematika pendidikan karakter sebagai respons atas berbagai persoalan bangsa terutama masalah dekadensi moral seperti korupsi, kekerasan, perkelahian antar pelajar, bentrok antar etnis dan perilaku seks bebas yang cenderung meningkat. Fenomena tersebut menurut Tilaar (1999: 3) merupakan salah satu ekses dari kondisi masyarakat yang sedang berada dalam masa transformasi sosial dalam menghadapi era globalisas.

Pulau Bali sebagai salah satu destinasi pariwisata di Indonesia bahkan di dunia memiliki seni dan budaya yang begitu unik, adiluhung, dan mempesona yang dalam berbagai aspek kehidupan masyarakatnya selalu berlandaskan dan berpedoman pada filosofi Tri Hita Karana dan dibingkai oleh nilai-nilai luhur agama Hindu juga tidak bisa terhindarkan dari permasalahan karakter yang senantiasa melilit keadaan sosial budaya masyarakat Bali.

Globalisasi yang berintikan pada kapitalisme dan perdagangan bebas, diikuti oleh masuknya modal asing, telah membawa Bali terseret pada mekanisme jejaring ideologi pasar. Nordholt (2005: xxix) menyebut hal ini sebagai "benteng terbuka", tidak kuasa melepaskan diri dari pengaruh globalisasi, bahkan jerat ideologi pasar ini membawa Bali pada sebutan "MacDonaldisasi of Bali" atau "Coca-Colanisasi of Bali". Selain itu, dalam istilah lain, Bali juga dapat dikatakan telah mengalami gejala "Amerikanisasi" atau "Westernisasi" (Atmadja, 2010: 113-114). Covarrubias (dalam Pitana, 1994: 4) menjelaskan "...kini terbukti bahwa perkembangan kepariwisataan telah membawa energi dobrak yang sangat dahsyat, sehingga menyebabkan perubahan-perubahan yang sangat struktural bagi masyarakat dan kebudayaan Bali".

Gambaran tersebut di atas menginterupsikan untuk kembali memperhatikan pentingnya pembangunan karakater (Character building) manusia yang berpijak kepada khazanah nilai-nilai kebudayaan Bali sebagai salah satu solusi alternatif melawan arus globalisasi, pariwisata dan modernisasi. Menurut Mochtar Lubis (1993: 257), kunci kesusksesan suatu bangsa yang memiliki kekuatan untuk menghadapi tantangan globalisasi dan budaya luar adalah pendidikan yang sanggup melengkapi anggota-anggota masyarakatnya dengan informasi dan pengetahuan yang luas dan mendalam. Oleh karena itu, pendidikan harus mampu mendidik manusia untuk menjadikan manusia yang berbudaya, dan bermoral dengan perekat nilai-nilai pendidikan karakter yang baik.

Nilai-nilai pendidikan karakter dapat diintegrasikan ke dalam seluruh pembelajaran pada setiap bidang studi yang terdapat dalam kurikulum (Mulyasa, 2011: 8). Salah satu mata pelajaran yang diajarkan disekolah yang memiliki keterkaitan dengan pendidikan karakter dan mampu mewadahi tujuan pendidikan karakter adalah mata pelajaran IPS (IImu Pengetahuan Sosial).Pada dasarnya pendidikan IPS memiliki tujuan untuk membina anak didik menjadi warga negara yang baik, yang memiliki pengetahuan, dan kepedulian sosial yang berguna bagi dirinya serta masyarakat dan negara. Oleh karena itu,sesuai dengan tujuan pendidikan IPS di atas, maka diperlukan pengintegrasian nilai-nilai karakter dalam pembelajaran IPS (Zuchdi, ddk 2013: 91-92).

Pada hakekatnya perjalanan kehidupan suatu kelompok masyarakat mereka biasanya berusaha mewujudkan serta kemudian mewariskan nilai-nilai karakter yang bisa dijadikan dasar pegangan bagi generasi berikutnya. Nilai-nilai itu biasanya melekat pada berbagai warisan sejarah/budaya, baik yang bersifat material maupun non material (ide/gagasan) (Widja, 2001: 4-5).

Peninggalan purbakala merupakan salah satu bentuk warisan sejarah/budaya yang sifatnya material yang banyak ditemui di Bali. Peninggalan purbakala merupakan bagian dari hasil kebudayaan manusia masa lampau dan merupakan bukti-bukti authentik yang tidak pernah ada duanya sebagai jawaban atau gagasan-gagasan manusia terhadap tantangan dari alam lingkungannya di satu pihak dan keperluan hidup sehari-hari yang semakin meningkat (Astawa, 2005: 2). Laksmi, dkk (2011: 1) berpendapat, bahwa peninggalan purbakala sebagai hasil cipta, karsa, dan karya manusia memiliki nilai-nilai luhur yang dapat dipetik guna dijadikan pedoman bagi kehidupan masyarakat dewasa ini. 
Bertolak dari makna peninggalan purbakala seperti yang sudah diuraikan oleh beberapa ahli di atas, maka peninggalan purbakala memiliki potensi untuk direnkonstruksi nilai-nilai pendidikan karakternya sebagai sarana pendidikan, baik sebagai sumber belajar maupun diintegrasikan ke dalamperangkat pembelajaran IPS.

Desa Pakraman Selulung merupakan salah satu desa Bali Aga/Kuna yang berada di wilayah Kecamatan Kintamani, Kabupaten Bangli, Bali (Sutedja dan Muliarsa, 1990: 1). Menurut Susila, dkk (2007), Desa Pakraman Selulung digolongkan sebagai salah satu desa kunakarena ditandai dengan masih survivenya sisa-sisa kebudayaan kuna yang masih diyakini dapat dijadikan pegangan di dalam menjalani kehidupan dalam upaya mencari kehidupan yang harmonis dan seimbang. Sisa-sisa kebudayaan kuna yang masih dapat ditemui di Desa Pakraman Selulung antara lain Arca Megalitik, Arca Tiongkok, Menhir, unsur bangunan berupa Tugehyang bermotifkan tanduk kerbau, Punden Berundak dan sebagainya (Susila, dkk, 2007: 1).

Peninggalanpurbakala tersebut menyimpan nilai-nilai luhur kearifan lokal masyarakat Desa Pakraman Selulung di masa lalu dan masa kini. Dengan demikian, peninggalan purbakala di Desa Pakraman Selulung memiliki potensi yang cukup besar untuk direkonstruksi nilai-nilai pendidikan karakternya sebagai sumber maupun media pembelajaran IPS di sekolah ataupun dalam rangka memperkuat identitas masyarakat Bali sebagai masyarakat yang religius, dan tetap mengedepankan nilai-nilai masa lalu dalam berfikir, berbicara dan bertindak.

Nilai-nilai pendidikan karakter yang terdapat di dalam peninggalan purbakala tersebut sedikit tidaknya merupakan jawaban dan/atau solusi dari berbagai fenomena kemerosotan karakter dan dekandensi moral yang dialami oleh masyarakat Bali sebagai dampak pengaruh globalisasi, modernisasi dan pariwisata.

Berdasarkan latar belakang yang telah diuraikan di atas, maka dapat dirumuskan permasalahan sebagai berikut: (1) Apa sajakah jenis peninggalan purbakala yang terdapat di Desa Pakraman Selulung, Kintamani, Bangli? (2) Nilai-nilai pendidikan karakter apakah yang terkandung di dalam peninggalan purbakala di Desa Pakraman Selulung, Kintamani, Bangli? (3) Nilai-nilai pendidikan karakter apa dari peninggalan purbakala di Desa Pakraman Selulung yang bisa dimanfaatkan sebagai sumber belajar IPS di SMP? (4) Bagaimanakah cara pengintegrasian nilai-nilai pendidikan karakter yang terdapat pada peninggalan purbakala di Desa Pakraman Selulung dalam perangkat pembelajaran IPS di SMP?

Landasan teori yang digunakan dalam penelitian ini adalah (1) Peninggalan Purbakala, (2) Pendidikan Karakter, (3) Teori Interaksi Simbolik, (4) Sumber Belajar IPS, Dan (5) Teori Konstruktivisme, (6) Pengembangan Perangkat Pembelajaran Berbasis NilaiNilai Pendidikan Karaktar.

Penelitian ini bertujuan untuk: (1) Mengidentifikasi jenis peninggalan purbakala yang ada di Desa Pakraman Selulung, Kintamani, Bangli, (2) Mengidentifikasi nilai-nilai pendidikan karakter yang terkandung di dalam peninggalan purbakala di Desa Pakraman Selulung, Kintamani, Bangli, (3) Menganalisis nilai-nilai pendidikan karakter pada peninggalan purbakala di Desa Pakraman Selulung yang bisa dimanfaatkan sebagai sumber belajar IPS di SMP, dan (4) Menganalisis cara mengintegrasikan nilai-nilai pendidikan karakter yang terdapat pada peninggalan purbakala di Desa Pakraman Selulung dalam perangkat pembelajaran IPS di SMP.

\section{METODE}

Metode penelitian yang digunakan dalam penelitian ini adalah metode penelitian kualitatif. Adapun langkah-langkah pada metode penelitian kualitatif adalah sebagai berikut: (1) Penentuan lokasi penelitian, dalam penelitian ini lokasi penelitian berada di Desa Pakraman Selulung, Kecamatan Kintamani, Kabupaten Bangli, Bali. (2) Metode penentuan informan, teknik penentuan informan dalam penelitian ini dilakukan secara purposive sampling, (3) Metode pengumpulan data, dalam penelitian ini teknik pengumpulan data yang digunakan adalah teknik observasi, teknik wawancara dan teknik studi dokumen. (4) Instrumen penelitian, dalam pengumpulan data peneliti menggunakan beberapa instrumen penelitian antara lain pedoman observasi, pedoman wawancara, taperecorder, buku catatan. 
(5) Metode pengujian keabsahan data, carayang digunakan dalam uji keabsahan hasil penelitian adalah dengan melakukan triangulasi metode, teori, dan sumber data. (6) Metode analisis data, dalam penelitian ini metode analisis data yang digunakan mencakup langkahlangkah yakni, reduksi data, display data, dan mengambil kesimpuan dan verifikasi.

\section{HASIL DAN PEMBAHASAN}

\section{HASIL}

\section{Peninggalan Purbakala Di Desa Pakraman Selulung}

Peninggalan purbakala yang terdapat di Desa Pakraman Selulung diantaranya adalah Punden Berundak Pelinggih I Ratu Gede Kemulan di Pura Candi, Punden Berundak Pelinggih I Ratu Dukuh Jegir di Pura Candi, Punden Berundak Pelinggih I Ratu Gede Kanginan di Pura Mihu, Punden Berundak Pelinggih I Ratu Gede Makarang di Pura Mihu, Punden Berundak Madya Petirtaan di Pura Bale Agung, 8 Buah Arca Megalitik di Pura Ulun Suwi, Menhir di Pura Ulun Suwi, Menhir di Pura Puseh Sinunggal, Hiasan Tanduk Kerbau Pada Tugeh Bale, Batu Alam di Pura Ulun Suwi, Pura Mihu dan Pura Mas, Lempengan Batu dan kerang (sungu) di Pura Mihu, Arca Bercorak Tiongkok di Pura Taulan, Arca Bercorak Hindu di Pura Arca Sabang, Arca Perunggu di Pura Pasek, Lingga Yoni di Pura Taman, Fragmen Lingga, Seperangkat Gamelan Gambang Kuno, Seperangkat Gamelan Selonding, Seperangkat Gamelan Gong Gede, Menhir dalam keadaan rebah, dan batu berbentuk roda di sekitar pura Dalem Mecantel.

\section{Rekonstruksi Nilai-Nilai Pendidikan Karakter Pada Peninggalan Purbakala Di Desa Pakraman Selulung}

Nilai-nilai pendidikan karakter yang terkandung di dalam peninggalan purbakala di Desa Pakraman Selulungadalah karakter religius, jujur, toleransi, disiplin, kerja keras, kreatif dan inovatif, mandiri, demokratis, rasa ingin tahu, cinta tanah air, gotong royong, hormat, peduli lingkungan, tanggung jawab, berani mengambil resiko, tangguh, terbuka, ramah dan luwes, moderat, dan seni.

\section{Nilai-Nilai Pendidikan Karakter Pada Peninggalan Purbakala Sebagai Sumber Belajar IPS Di SMP}

Nilai-nilai pendidikan karakter hasil rekonstruksi pada peninggalan purbakala di Desa Pakraman Selulung dapat dimanfaatkan sebagai sumber belajar IPS Di SMP Negeri 2 Kintamani. Salah satunya dapat dimanfaatkan pada standar kompetensi "memahami lingkungan kehidupan manusia" dan kompetensi dasar "mendeskripsikan kehidupan pada masa pra aksara di Indonesia" di kelas VII pada kurikulum tingkat satuan pendidikan (KTSP) yang berlaku di SMP Negeri 2 Kintamani.

\section{Integrasi Nilai-Nilai Pendidikan Karakter Pada Peninggalan Purbakala Di Desa Pakraman Selulung Dalam Perangkat Pembelajaran}

Nilai-nilai pendidikan karakter hasil rekonstruksi pada peninggalan purbakala di Desa Pakraman Selulung diintegrasikan ke dalam mata pelajaran IPS di SMP Negeri 2 Kintamani pada standar kompetensi "memahami lingkungan kehidupan manusia" dan kompetensi dasar "mendeskripsikan kehidupan pada masa pra aksara di Indonesia". Caranya adalah dengan mengintegrasikannya pada perangkat pembelajaran, yakni ke dalam silabus dan rencana pelaksanaan pembelajaran (RPP) pada kurikulum tingkat satuan pendidikan (KTSP). Aspek-aspek dalam silabus dan rencana pelaksanaan pembelajaran (RPP) yang diintegrasikan dengan nilai-nilai pendidikan karakter mecakup tujuan pembelajaran, indikator pembelajaran, materi ajar, strategi dan metode pembelajaran, langkah-langkah pembelajaran, dan penilaian pembelajaran. 


\section{PEMBAHASAN}

Peninggalan purbakala merupakan bukti-bukti authentik yang tidak pernah ada duanya sebagai jawaban atau gagasan-gagasan manusia terhadap tantangan dari alam lingkungannya di satu pihak dan keperluan hidup sehari-hari yang semakin meningkat (Astawa, 2005: 2). Selanjutnya, menurut UU RI Nomer 11 Tahun 2010 Cagar Budaya atau situs peninggalan purbakala perlu dilestarikan keberadaanya karena memiliki nilai penting bagi sejarah, ilmu pengetahuan, pendidikan, agama, dan kebudayaan melalui proses penetapan (Laksmi, dkk, 2011: 7).

Desa Pakraman Selulung merupakan salah satu desa Bali Aga/Kuna yang berada di wilayah Kecamatan Kintamani, Kabupaten Bangli, Bali (Sutedja dan Muliarsa, 1990: 1). Sisasisa kebudayaan kuna yang masih dapat ditemui di Desa Pakraman Selulung antara lain Arca Megalitik, Arca Tiongkok, Menhir, unsur bangunan berupa Tugeh yang bermotifkan tanduk kerbau, Punden Berundak dan sebagainya (Susila, dkk, 2007: 1).

Sisa-sisa kebudayaan kuna yang terdapat di Desa Pakraman Selulung juga dijelaskan oleh Sutaba (1980: 28-29), yaitu sebagai berikut:

"...tradisi megalitik di desa-desa pegunungan yang terletak di sebelah barat Kintamani, antara lain desa Selulung, Pengejaran, Batukaang, Binyan, dan desadesa sekitarnya. Di situ ditemukan bentuk-bentuk megalitik seperti menhir, dolmen, sarkofagus, teras piramid (punden berundak), dan lain-lainnya.

I Dewa Gede Anom Wayhu (56) juga menuturkan mengenai peninggalan kepurbakalaan yang terdapat di Desa Pakraman Selulung, yakni:

"Di Desa Pakraman Selulung yang mencakup wilayah Desa Dinas Belantih dan Desa Dinas Selulung terdapat berbagai macam peninggalan purbakala seperti Yoni, Lingga, Madya/Punden Berundak, batu berdiri/Menhir, Arca Sederhana, Kursi Batu, Arca bermotif Tiongkok, gambar Surya Sengkala pada bale pajenengan, kerang/sungu, lepengan batu, gambang dan selonding, seperangkat Gong Gede/Gong Patuturan, Pejenengan berupa Keris Tateken (Tongkat), Sutra Pitola Kuno, dan prasasti Belantih yang sekarang di simpan oleh salah seorang warga di Desa Sawan" (Hasil wawancara tanggal 5 Februari 2015).

Mengenai peninggalan purbakala yang terdapat di Desa Pakraman Selulung dapat dilihat pada tabel 1. Jika menyimak peninggalan-peninggalan kepurbakalaan tersebut dapat disimpulkan bahwa Desa Pakraman Selulung merupakan desa kuna yang memiliki peninggalan purbakala yang cukup beragam berupa peninggalan purbakala bercorak tradisi megalitik dan peninggalan purbakala bercorak Hinduistik (Sutedja dan Muliarsa, 1990: 15)

Tebel 1 Peninggalan purbakala di Desa Pakraman Selulung

\begin{tabular}{|c|c|c|c|c|c|}
\hline No. & Peninggalan Purbakala & Periode & \multicolumn{2}{|c|}{ Letak } & Jumlah \\
\hline 1. & $\begin{array}{l}\text { Punden } \\
\text { Pelinggih I Ratu Gede } \\
\text { Kemulan }\end{array}$ & Megalitik/Prasejarah & \multicolumn{2}{|c|}{ Pura Candi } & 1 \\
\hline 2. & $\begin{array}{l}\text { Punden Berundak } \\
\text { Pelinggih I Ratu Dukuh } \\
\text { Jegir }\end{array}$ & Megalitik/Prasejarah & \multicolumn{2}{|c|}{ Pura Candi } & 1 \\
\hline 3. & $\begin{array}{l}\text { Punden Berundak } \\
\text { Pelinggih I Ratu Gede } \\
\text { Kanginan }\end{array}$ & Megalitik/Prasejarah & \multicolumn{2}{|c|}{ Pura Mihu } & 1 \\
\hline 4. & $\begin{array}{l}\text { Punden Berundak } \\
\text { Pelinggih I Ratu Gede } \\
\text { Makarang }\end{array}$ & Megalitik/Prasejarah & \multicolumn{2}{|c|}{ Pura Mihu } & 1 \\
\hline 5. & $\begin{array}{l}\text { Punden Berundak } \\
\text { Madya Petirtaan }\end{array}$ & Megalitik/Prasejarah & $\begin{array}{l}\text { Pura } \\
\text { Agung }\end{array}$ & Bale & 1 \\
\hline 6. & Arca Megalitik & Megalitik/Prasejarah & $\begin{array}{l}\text { Pura } \\
\text { Suwi }\end{array}$ & Ulun & 8 \\
\hline
\end{tabular}




\begin{tabular}{|c|c|c|c|c|}
\hline 7. & Menhir & Megalitik/Prasejarah & $\begin{array}{l}\text { Pura } \\
\text { Suwi }\end{array}$ & 20 \\
\hline 8. & Menhir & Megalitik/Prasejarah & $\begin{array}{l}\text { Pura Puseh } \\
\text { Sinunggal }\end{array}$ & 1 \\
\hline 9. & $\begin{array}{l}\text { Hiasan Tanduk Kerbau } \\
\text { Pada Tugeh Bale }\end{array}$ & Sejarah/Aksara & $\begin{array}{l}\text { Sebagai besar } \\
\text { Pura }\end{array}$ & *** \\
\hline 10. & Batu Alam & Megalitik/Prasejarah & $\begin{array}{l}\text { Pura Ulun } \\
\text { Suwi }\end{array}$ & 27 \\
\hline 11. & Batu Alam & Megalitik/Prasejarah & Pura Mas & 8 \\
\hline 12. & Batu Alam & Megalitik/Prasejarah & Pura Mihu & 11 \\
\hline 13. & Lempengan Batu & Megalitik/Prasejarah & Pura Mihu & 1 \\
\hline 14. & Kerang (Sungu) & Sejarah/Aksara & Pura Mihu & 2 \\
\hline 15. & $\begin{array}{ll}\text { Arca } & \text { Bercorak } \\
\text { Tiongkok } & \end{array}$ & Sejarah/Aksara & Pura Taulan & 2 \\
\hline 16. & Arca Bercorak Hindu & Sejarah/Aksara & $\begin{array}{ll}\text { Pura } & \text { Arca } \\
\text { Sabang } & \end{array}$ & 2 \\
\hline 17. & Arca Perunggu & Sejarah/Aksara & Pura Pasek & 2 \\
\hline 18. & Lingga Yoni & Sejarah/Aksara & Pura Taman & 3 \\
\hline 19. & Fragmen Lingga & Sejarah/Aksara & Pura Taulan & $* * *$ \\
\hline 20. & $\begin{array}{l}\text { Seperangkat Gamelan } \\
\text { Gambang Kuno }\end{array}$ & Sejarah/Aksara & $\begin{array}{l}\text { Bale } \\
\text { Penyimpenan }\end{array}$ & 1 \\
\hline 21. & $\begin{array}{l}\text { Seperangkat Gamelan } \\
\text { Selonding }\end{array}$ & Sejarah/Aksara & & 1 \\
\hline 22. & $\begin{array}{l}\text { Seperangkat Gamelan } \\
\text { Gong Gede }\end{array}$ & Sejarah/Aksara & $\begin{array}{l}\text { Pura Bale } \\
\text { Agung }\end{array}$ & 1 \\
\hline 23. & $\begin{array}{l}\text { Menhir Dalam } \\
\text { Keadaan Rebah }\end{array}$ & Megalitik/Prasejarah & $\begin{array}{l}\text { Pura Dalem } \\
\text { Mecantel }\end{array}$ & 2 \\
\hline 24. & Batu Berbentuk Roda & Megalitik/Prasejarah & $\begin{array}{l}\text { Pura Dalem } \\
\text { Mecantel }\end{array}$ & 2 \\
\hline
\end{tabular}

Keterangan:* : Jumlahnya banyak/Sulit dihitung

Benda-benda peninggalan purbakala sangat penting karena dapat memberikan pengetahuan terhadap sejarah kebudayaan masa lalu, cara-cara hidup, maupun prosesproses budaya yang pernah terjadi (Kusumohartono dalam Suantika, 2002: 12).Laksmi, dkk (2011: 1) juga berpendapat, bahwa peninggalan purbakala sebagai hasil cipta, karsa, dan karya manusia memiliki nilai-nilai luhuryang dapat dipetik guna dijadikan pedoman bagi kehidupan masyarakat dewasa ini.

Sementera itu, menurut Widja (2001: 5), bahwa warisan budaya tidak lain adalah warisan nilai-nilai sosial budayasuatu kelompok masyarakat yang merupakan akar dari mana mereka menemukan jati diri mereka.

Menyimak beberapa fungsi dan potensi nilai-nilai yang terkandung di dalam peninggalan purbakala seperti yang sudah diuraikan di atas, maka peninggalan-peninggalan purbakala yang terdapat di Desa Pakraman Selulung memiliki potensi untuk direkonstruksi nilai-nilai pendidikan karakternya. Hal ini untuk menyikapi berbagai persoalan-persoalan yang dialami oleh bangsa Indonesia dan masyarakat Bali pada khususnya yang sudah mengalami kemerosotan karakter dan dekandensi moral sebagai dampak perkembangan globalisasi, modernisasi, dan pariwisata.

Menurut Kamus Besar Bahasa Indonesia, rekonstruksi memiliki arti pengembalian seperti semula, penyusunan (penggambaran) kembali, dan merekonstruksikan memiliki arti mengembalikan (memulihkan) sebagai semula, menyusun (menggambarkan) kembali suatu peristiwa atau kejadian seperti adanya semula (Tim Penyusun, 2008: 1284). Oleh karena itu, "Rekonstruksi Nilai-Nilai Pendidikan Karakter Pada Peninggalan Purbakala Di Desa Pakraman Selulung" memiliki makna membangun (menyusun/memulihkan) kembali nilai-nilai 
pendidikan karakter yang terkandung di dalam peninggalan purbakala di Desa Pakraman Selulung.

Pada konteks tersebut, nilai-nilai pendidikan karakter pada peninggalan purbakala di Desa Pakraman Selulung perlu direkonstruksi (dibangun/disusun) kembali dalam arti menjadikannya sebagai pengetahuan yang bermakna, dan dapat dijadikan sebagai sumber belajar yang setara dengan sumber belajar dominan (wacana besar).

Sementara itu, karakter adalah gambaran tingkah laku yang dimiliki oleh seseorang yang mencerminkan nilai-nilai kehidupan dan melekat pada diri seseorang (Rohman, 2012: 232). Nilai-nilai pendidikan karakter hasil rekonstruksi pada peninggalan purbakala di Desa Pakraman Selulung antara lain adalah karakter religius, jujur, toleransi, disiplin, kerja keras, kreatif dan inovatif, mandiri, demokratis, rasa ingin tahu, cinta tanah air, gotong royong, hormat, peduli lingkungan, tanggung jawab, berani mengambil resiko, tangguh, terbuka, ramah dan luwes, moderat, dan seni.

Nilai-nilai pendidikan karakter tersebut sangat penting dalam usaha menjaga kesinambungan pembangunan dan landasan kepribadian bangsa yang kokoh yang disangga oleh ketahanan budaya yang tangguh dan dinamis. Dengan demikian, nilai-nilai pendidikan karakter hasil rekonstruksi pada peninggalan purbakala di Desa Pakraman Selulung dapat dikembangkan sebagai sumber belajar IPS di SMP dengan diintegrasikan ke dalam perangkat pembelajaran IPS.

Pendidikan IPS adalah penyederhanaan atau adaptasi dari disiplin ilmu-ilmu sosial dan humaniora, serta kegiatan dasar manusia yang diorganisasikan dan disajikan secara ilmiah dan pedagogis/psikologis untuk tujuan pendidikan (Somantri, 2001: 92). Sementara itu, tujuan pendidikan IPS menurut Muchtar (2001: 33) adalah untuk mengembangkan kemampuan baik intelektual maupun emosional siswa untuk dapat memahami dan memecahkan masalah sosial dalam rangka memperkuat partisipasi sebagai warga negara dalam kehidupan masyarakat.

Jika menyimak permasalahan yang dihadapi oleh masyarakat Bali dan Indonesia pada umumnya yang menyangkut dekandensi moral dan kemerosotan karakter, seperti meningkatnya pergaulan bebas, maraknya angka kekerasan anak-anak dan remaja, kejahatan terhadap teman, pencurian remaja, kebiasaan menyontek, penyalahgunaan obatobatan, pornografi, perkosaan, perampasan, dan perusakan milik orang lain merupakan sebuah krisis moral yang sudah menjadi masalah sosial yang hingga saat ini belum dapat diatasi secara tuntas (Zubaedi, 2011: 1-2).

Oleh karena itu, sudah seyogyanya pendidikan IPS harus menjadi aktor utama dalam menyelesaikan berbagai bentuk permasalahan-permasalahan dekandensi moral dan kemerosotan karakter tersebut di atas. Hal tersebut sesuai dengan pendapat Hasan (1995: 116) yang menyatakan pendidikan IPS memiliki kewajiban untuk mengembangkan nilai dan moral yang berlaku dalam masyarakat menjadi bagian dari kepribadian individu siswa, sehingga melaui cara demikian maka pendidikan IPS mampu memberikan kontribusi tidak hanya untuk kepentingan dirinya (keilmuannya) tetapi juga untuk kepentingan masyarakat yang telah mempercayakan tugas itu melalui rumusan tujuan pendidikan nasional, undangundang, maupun keputusan-keputusan tentang pendidikan yang lebih operasional.

Lebih lanjut dijelaskan oleh Zubaedi (2011: 291) yang menyatakan "Mata pelajaran IPS akan lebih optimal dalam ikut membangun karakter peserta didik jika dilakukan dengan manajemen pembelajaran yang tepat". Apalagi sesuai dengan tujuan pendidikan IPS untuk membentuk warga negara yang baik, yaitu generasi muda yang humanis, rasional, dan partisipatif dalam kehidupannya dan mempunyai sikap sosial dalam bentu suka menolong, kepedulian, toleransi, dan dapat bekerjasama dengan orang lain maka nampaknya diperlukan pengintegrasian nilai-nilai karakter dalam pembelajaran IPS (Zuchdi, ddk 2013: 91-92).

Oleh karena itu, nilai-nilai pendidikan karakter hasil rekonstruksi pada peninggalan purbakala di Desa Pakraman Selulung di atas dapat dimanfaatkan sebagai sumber belajar IPS Di SMP Negeri 2 Kintamani yang diintegrasikan ke dalam kurikulum tingkat satuan pendidikan (KTSP) kelas VII. 
Dalam konteks pegintegrasian nilai-nilai pendidikan karakter ke dalam kurikulum tingkat satuan pendidikan (KTSP) pada kelas VII di SMP Negeri 2 Kintamani dapat diintegrasikan pada perangkat pembelajaran yang dipakai oleh guru dalam kegiatan belajar mengajar. Hal ini dilakukan untuk menciptakan sebuah perangkat pembelajaran IPS berbasis karakter. Perangkat pembelajaran merupakan perangkat yang digunakan dalam proses pembelajaran di sekolah (Trianto, 2009: 201). Melalui penyusunan perangkat pembelajaran, guru akan memiliki keunggulan dengan persiapan yang matang dan terpola dalam membangun sistem dalam pembelajaran yang efektif (Sahlan dan Prastyo, 2012: 50).

Pengembangan perangkat pembelajaran berbasis karakter harus memperhatikan minat dan perhatian peserta didik terhadap materi standar yang dijadikan bahan kajian. Dalam hal ini, harus diperhatikan agar guru tidak hanya berperan sebagai transformator, akan tetapi harus berperan sebagai motivator yang dapat membangkitkan gairah dan nafsu belajar, serta mendorong peserta didik untuk belajar, dengan menggunakan berbagai variasi media, dan sumber belajar yang sesuai, serta menunjang pembentukan karakter secara utuh (Mulyasa, 2011: 83).

Nilai-nilai pendidikan karakter hasil rekonstruksi pada peninggalan purbakala di Desa Pakraman Selulung dapat diintegrasikan pada perangkat pembelajaran IPS, yakni ke dalam silabus dan rencana pelaksanaan pembelajaran (RPP) IPS kurikulum tingkat satuan pendidikan (KTSP). Sejalan dengan pengintegrasian nilai-nilai pendidikan karakter, Zubaedi berpendapat, bahwa:

"Pendidikan karakter bukan merupakan mata pelajaran baru yang berdiri sendiri, bukan pula dimasukkan ke dalam standar kompetensi dan kompetensi dasar baru, tetapi terintegrasi ke dalam mata pelajaran yang sudah ada, pengembangan diri dan budaya sekolah serta muatan lokal. Oleh karena itu, guru dan sekolah perlu mengintegrasikan nilai-nilai yang dikembangkan dalam pendidikan karakter ke dalam Kurikulum Tingkat Satuan Pendidikan (KTSP), Silabus, dan Rencana Program Pembelajaran (RPP) yang sudah ada" (Zubaedi, 2011: 137-138).

Silabus merupakan salah satu produk pengembangan kurikulum yang berisikan garis-garis materi pelajaran, kegiatan pembelajaran, dan rancangan penilaian (Trianto, 2009: 201). Intergrasi Nilai-nilai pendidikan karakter hasil rekonstruksi pada peninggalan purbakala di Desa Pakraman Selulung pada silabus IPS kurikulum tingkat satuan pendidikan (KTSP) dilakukan melalui proses adaptasi dan perbaikan terhadap silabus yang sudah dipakai oleh guru dalam kegiatan belajar mengajar di SMP Negeri 2 Kintamani. Caranya adalah dengan mengadaptasi dan memperbaiki silabus, dengan menambah kolom karakter sehingga akan memfasilitasi peserta didik untuk mengenal nilai-nilai pendidikan karakter hasil rekonstruksi pada peninggalan purbakala di Desa Pakraman Selulung.

Hal tersebut sesuai dengan penjelasan Sulistyowati (2012: 100) yang menguraikan bahwa cara mudah untuk membuat silabus yang berwawasan pendidikan karakter adalah dengan mengadaptasi silabus dan bahan ajar yang telah ada, dengan menambah kolom karakter atau mengadaptasi kegiatan pembelajaran yang bersifat memfasilitasi dikenalnya nilai-nilai, disadari pentingnya nilai-nilai, dan diinternalisasinya niali-nilai.

Sementara itu, rencana pelaksanaan pembelajaran (RPP) adalah panduan langkahlangkah yang akan dilakukan oleh guru dalam kegiatan pembelajaran yang disusun dalam skenario kegiatan (Trianto, 2009: 214). Sedangkan, rencana pelaksanaan pembelajaran (RPP) berbasis karakter adalah rencana jangka pendek untuk memperkirakan atau memproyeksikan karakter yang akan ditanamkan kepada peserta didik dalam pembelajaran (Mulyasa, 2011: 78). Dengan demikian, RPP berbaisis karakter merupakan upaya memperkirakan tindakan-tindakan yang akan dilakukan dalam kegiatan pembelajaran untuk membentuk, membina, dan mengembangkan karakter peserta didik, sesuai dengan standar kompetensi (SK), dan kompetensi dasar (KD).

Intergrasi Nilai-nilai pendidikan karakter hasil rekonstruksi pada peninggalan purbakala di Desa Pakraman Selulung pada RPP IPS kurikulum tingkat satuan pendidikan 
(KTSP) dilakukan melalui proses adaptasi dan perbaikan terhadap RPP yang sudah dipakai oleh guru dalam kegiatan belajar mengajar di SMP Negeri 2 Kintamani.

Langkah-langkah yang dilakukan dalam menyusun RPP IPS berbasis karakter adalah:

1. Pertama, tujuan dan indikator pembelajaran diadaptasi dan diperbaiki dengan menambah frase yang merupakan karakter atau indikator nilai karakter hasil rekonstruksi pada peninggalan purbakala di Desa Pakraman Selulung

2. Kedua, materi ajar.Materi ajar merupakan komponen pembelajaran yang paling berpengaruh terhadap apa yang sesungguhnya terjadi pada proses pembelajaran. Oleh karena itu, nilai-nilai pendidikan karakter perlu disisipkan pada pada materi ajar untuk membiasakan peserta didik dalam mengembangkan karakternya.

3. Ketiga, strategi dan metode pembelajaran diubah agar strategi dan metode yang dipilih selain memfasilitasi siswa mencapai kompetensi mata pelajaran, juga dapat membiasakan pengembangan karakter. Strategi dan metode pembelajaran yang dipakai untuk mengembangkan karakter siswa adalah strategi cooperative learning tipe jigsaw.

4. Keempat, langkah-langkah pembelajaran diperbaiki. Kegiatan-kegiatan pembelajaran dalam setiap langkah pembelajaran (pendahuluan, inti, dan penutup) diperbaiki dan/atau ditambah agar kegiatan pembelajaran pada setiap tahapan memfasilitasi siswa memperoleh kompetensi mata pembelajaran dan sekaligus membiasakan pengembangan karakter.

5. Kelima, bagian penilaian diperbaiki. Perbaikan dilakukan dengan cara mengubah dan/atau menambah teknik-teknik penilaian yang dapat mengukur karakter peserta didik.

Pendapat tersebut di atas relevan dengan penjelasan Sulistyowati (2012: 112) yang menyatakan bahwa penyususnan RPP terintegrasi dengan nilai budaya dan karakter bangsa dapat dilakukan dengan cara melakukan adaptasi dan perbaikan RPP yang sudah ada sebelumnya. Bentuk adaptasi yang dimaksud adalah sebagai berikut:

1. Penambahan dan/atau modifikasi tujuan pembelajaran sehingga pembelajaran tidak hanya membantu siswa mencapai KD, tetapi juga mengembangkan karakternya.

2. Penambahan dan/atau modifikasi kegiatan pembelajaran sehingga ada kegiatan pembelajaran yang mengembangkan karakter.

3. Penambahan dan/atau modifikasi indikator pencapaian sehingga ada indikator yang terkait dengan pencapaian siswa dalam hal karakter.

4. Penambahan dan/atau modifikasi teknik penilaian sehingga ada teknik penilaian yang dapat mengembangkan dan/atau mengukur perkembangan karakter (Sulistyowati, 2012: 112).

\section{Simpulan dan Saran}

Peninggalan purbakala yang terdapat di Desa Pakraman Selulung diantaranya adalah 5 buah Punden Berundak, 8 Buah Arca Megalitik, Menhir, Hiasan Tanduk Kerbau, Batu Alam, Lempengan Batu dan kerang (sungu), Arca Bercorak Tiongkok, Arca Bercorak Hindu, Arca Perunggu, Lingga Yoni, Fragmen Lingga, seperangkat Gamelan Gambang Kuno, seperangkat Gamelan Selonding, seperangkat Gamelan Gong Gede, Menhir dalam keadaan rebah, dan batu berbentuk roda.

Peninggalan purbakala tersebut mengandung nilai-nilai pendidikan karakter antara lain adalah karakter religius, jujur, toleransi, disiplin, kerja keras, kreatif dan inovatif, mandiri, demokratis, rasa ingin tahu, cinta tanah air, gotong royong, hormat, peduli lingkungan, tanggung jawab, berani mengambil resiko, tangguh, terbuka, ramah dan luwes, moderat, dan seni.

Nilai-nilai pendidikan karakter hasil rekonstruksi pada peninggalan purbakala di Desa Pakraman Selulung di atas sangat berpotensi untuk dimanfaatkan sebagai sumber belajar IPS Di SMP Negeri 2 Kintamani pada standar kompetensi "memahami lingkungan kehidupan manusia" dan kompetensi dasar "mendeskripsikan kehidupan pada masa pra aksara di Indonesia" di kelas VII pada kurikulum tingkat satuan pendidikan (KTSP). Caranya adalah diintegrasikan ke dalam aspek-aspek yang terdapat pada silabus dan rencana pelaksanaan 
pembelajaran (RPP).Aspek-aspek tersebut mecakup tujuan pembelajaran, indikator pembelajaran, materi ajar, strategi dan metode pembelajaran, langkah-langkah pembelajaran, dan penilaian pembelajaran.

Jika menyimak potensi dan nilai-nilai yang terkandung di dalam peninggalan purbakala di Desa Pakraman Selulung diharapkan kepada seluruh masyarakat Desa Pakraman Selulung dan juga pemerintah agar lebih intensif dalam menjaga dan melestarikan peninggalan-peninggalan kepurbakalaan tersebut. Agar eksistensi Peninggalan ini bisa terus di nikmati oleh generasi selanjutnya.

\section{UCAPAN TERIMA KASIH}

Ucapan terima kasih penulis ditujukan kepada:

1. Dr. Luh Putu Sendratari, M.Hum selaku pembimbing lyang telah banyak meluangkan waktunya kepada penulis dalam memberikanpengetahuannya, memotivasi dan membimbing penulis dalam penyusunan artikel.

2. Dr. I Ketut Margi, M.Si selaku pembimbing llyang telah memberikan saran dan membimbing penulis dalam penyusunan artikel.

\section{DAFTAR RUJUKAN}

Astawa, A. A. Gede Oka. 2005. Sumber Daya Arkeologi di Situs Jero Agung Bedulu Dalam Pengembangan Pariwisata Budaya. Dalam Khasanah Arkeologi: Pemanfaatan Sumberdaya Arkeologi. (Ed. I Made Sutaba). Denpasar: Ikatan Ahli Arkeologi Komda Bali, Balai Arkeologi. Halaman: 1-16

Atmadja, N.B. 2010. Ajeg Bali: Gerakan, Identitas Kultural, dan Globalisasi. Yogyakarta: LKiS

Hasan, S. Hamid. 1995. Pendidikan IImu Sosial. Jakarta: Departemen Pendidikan dan Kebudayaan

Laksmi, dkk. 2011. Cagar Budaya Bali: Menggali Kearifan Lokal Dan Model Pelestariannya. Denpasar: Udayana University Press

Lubis, Mochtar. 1993. Budaya, Masyarakat Dan Manusia Indonesia. Jakarata: Yayasan Obor Indonesia

Muchtar, Suwarma Al. 2001. Epistimologi Pendidikan IImu Pengetahuan Sosial. Bandung: Gelar Pustaka Mandiri.

Mulyasa, H. E. 2011. Manajemen Pendidikan Karakter. (Ed. Dewi Ispurwati). Jakarta: Bumi Aksara

Nordholt, H.S. 2005. "Bali: Sebuah Benteng Terbuka". Pengantar dalam Bali: Narasi Dalam Kuasa Politik dan Kekerasan di Bali. Yogyakarta: Ombak.

Pitana, I Gde. 1994. "Mosaik Masyarakat dan Kebudayaan Bali". Dalam Dinamika Masyarakat Dan Kebudayaan Bali (Editor: I Gde Pitana). Denpasar: Ofset BP. Halaman: 3-16

Rohman, Muhammad. 2012. Kurikulum Berkarakter (Refleksi dan Proposal Solusi Terhadap KBK dan KTSP). (Ed. Umi Athelia Kurniawati). Jakarta: Prestasi Pustaka

Sahlan, Asmaun dan Angga Teguh Prastyo. 2002. Desain Pembelajaran Berbasis Pendidikan Karakter. Ed. Rina Tyas Sari. Yogyakarta: Ar-Puzz Media 
Somantri, Muhammad Numan. 2001. Menggagas Pembaharuan Pendidikan IPS. Bandung: Remaja Rosdakarya

Suantika, W. 2002. Bukti-Bukti Kehidupan Purba Pada Beberapa Lokasi Di Kecamatan Grokgak, Kabupaten Buleleng. Dalam Forum Arkeologi. Denpasar: Balai Arkeologi Denpasar. Halaman 12-26

Sujana, Nyoman Naya. 1994. "Manusia Bali Di Persimpangan Jalan". Dalam Dinamika Masyarakat Dan Kebudayaan Bali (Editor: I Gde Pitana). Denpasar: Ofset BP. Halaman: 45-71

Sulistyowati, Endah. 2012. Implementasi Kurikulum Pendidikan Karakter (Dilengkapi Cara Menyusun dan Contoh Dokumen KTSP, Silabus, RPP Integrasi Nilai Budaya dan Karakter Bangsa). Ed. M. Safrudin. Yogyakarta: PT Citra Aji Parama

Susila, I Wayan, dkk. 2007. Laporan Studi Teknis Pura Miyu dan Pura Candi Desa Selulung, Kecamatan Kintamani, Kabupaten Bangli. Denpasar: Balai Pelestarian Peninggalan Purbakala Provinsi Bali, NTB, dan NTT

Sutaba, I Made. 1980. Beberapa Catatan Tentang Tradisi Megalitik Di Bali. Dalam Pertemuan IImiah Arkeologi. Jakarta: Offset PT Rora Karya. Halaman 27-37

Sutedja, I Wayan dan I Wayan Muliarsa. 1990. Laporan Pengumpulan Data Kepurbakalaan Di Desa Selulung dan Sekitarnya. Gianyar: Suaka Peninggalan Sejarah dan Purbakala Bali-NTB-NTT-TIMTIM

Tilaar, H.A.R. 1999. Pendidikan, Kebudayaan, dan Masyarakat Madani Indonesia, Strategi Reformasi Pendidikan Nasional. Bandung: Remaja Rosdakarya

Tim Penyusun. 2008. Kamus Bahasa Indonesia. Jakarta: Pusat Bahasa Departemen Pendidikan Nasional

Trianto. 2009. Mendesain Model Pembelajaran Inovatif Progresif: Konsep, Landasan, dan Implementasinya Pada Kurikulum Tingkat Satuan Pendidikan (KTSP). Jakarta: Kencana Prenada Media Group

Widja, I Gde. 2001. Menengok Kembali Studi Sejarah Lokal dalam Era Globalisasi. Dalam Jurnal Candra Sangkala Edisi Khusus. Singaraja: Program Studi Pendidikan Sejarah IKIP Negeri Singaraja. Halaman: 1-7

Zubaedi. 2011. Desain Pendidikan Karakter: Konsep dan Aplikasinya Dalam Lembaga Pendidikan. Jakarta: Kencana Prenada Media Group

Zuchdi, Damiyanti, dkk. 2013. Model Pendidikan Karakter Terintegrasi Dalam Pembelajaran dan Perkembangan Kultur Sekolah. Yogyakarta: Perpustakaan Nasional 